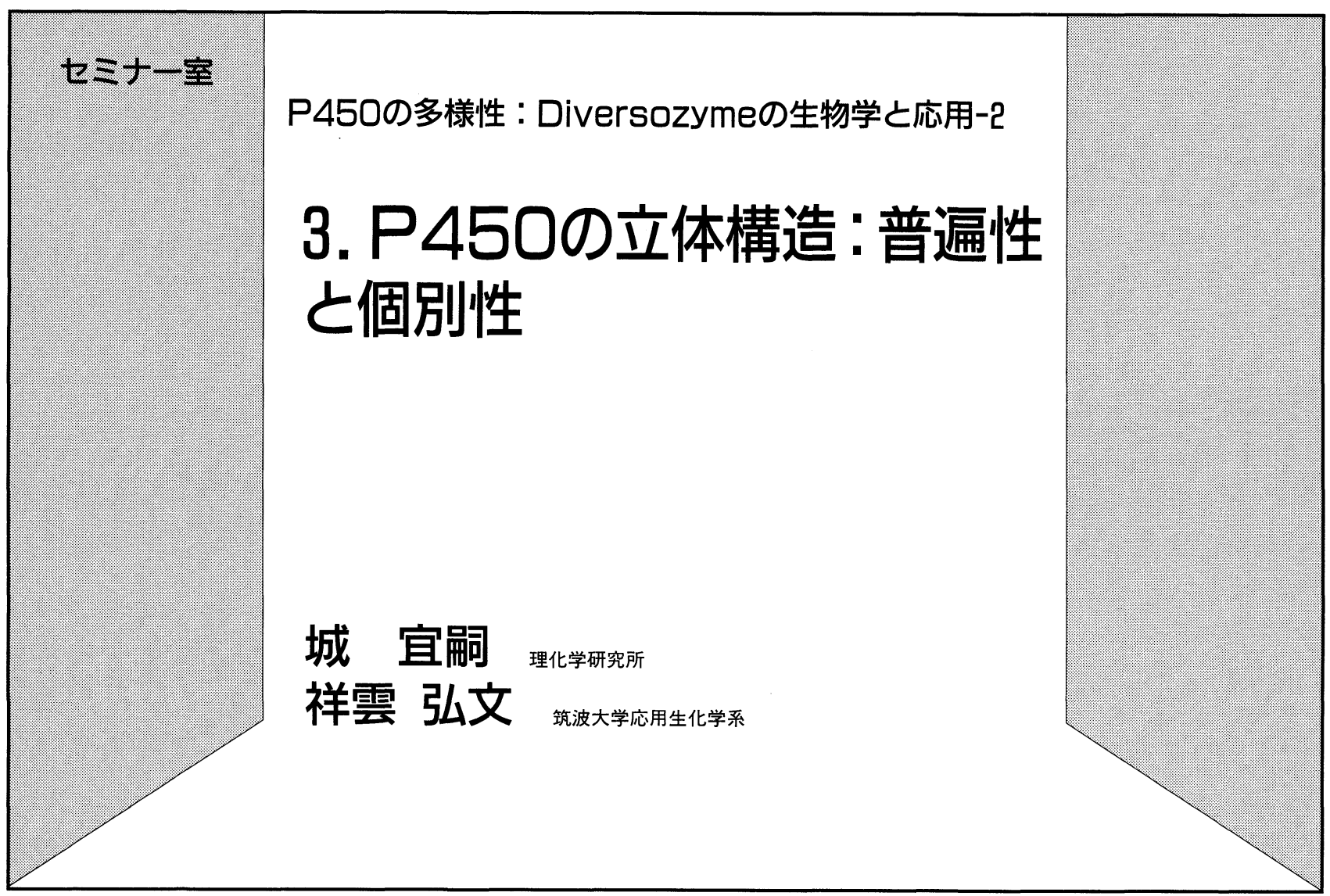

蛋白質・酵素の構造を基にそれらの機能を議論する学 問, いわゆる構造生物学は, 現代生物学の 1 つの流れで ある、チトクロム P450の研究に構造生物学的な手法が 適用されるようになったのは, 1985 年のPseudomonas putida $\mathrm{P} 450_{\text {cam }}$ の結晶構造の報告に始まる(1). それ以 降, Bacillus megaterium P450BM-3 ${ }^{(2)}$, Pseudomanad $\mathrm{P}_{450}$ terp $^{(3)}$, Saccharopolyspora erythaea $\mathrm{P} 450_{\mathrm{ery}} \mathrm{F}^{(4)}$, Fusarium oxysporum $\mathrm{P} 450_{\mathrm{nor}}{ }^{(5)}$ の全部で 5 つの $\mathrm{P} 450$ の結晶構造が報告され, 遺伝子工学的手法の発展とあい まって, これらの構造を基に $\mathrm{P} 450$ の触媒反応を分子・ 原子のレベルで語ることができるようになってきた。本 稿では, これら P450 の立体構造を見ながら, P450スー パーファミリーとしての普遍的な, さらに個々の酵素の 個性的な構造・性質について述べる.

\section{P450 の立体構造}

\section{1. 全体構造}

図 1 に上記 5 つの $\mathrm{P} 450$ の全体構造を示した。どの $\mathrm{P} 450$ も一辺約 $65 \AA$ の三角形, 厚みは約 $35 \AA$ のオムスビ 型の分子構造で, 図 1 でいうと右下半分の $\alpha$ ヘリック スの多い領域と左上の $\beta$ シート・ランダムコイルの多い 領域でできている. 活性中心であるへムは分子の中心に 位置しており, 溶媒の水には露出していない. へムの第 六配位座上部を通り, 分子の中心を貫くように 30 数残 基のアミノ酸よりなる長い I ヘリックスが存在してい る.また，図には示していないが，へム鉄の第五配位子 である Cys を取り囲む構造 (Cys リガンドループ), へム のプロピオン酸側鎖とその周辺との相互作用, meander 


\section{(a)}

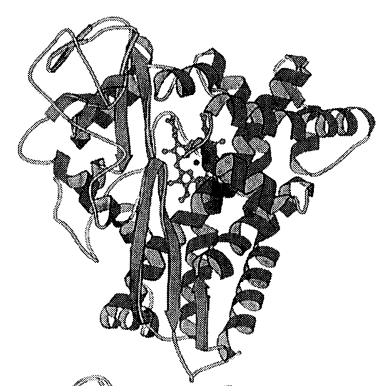

(b)
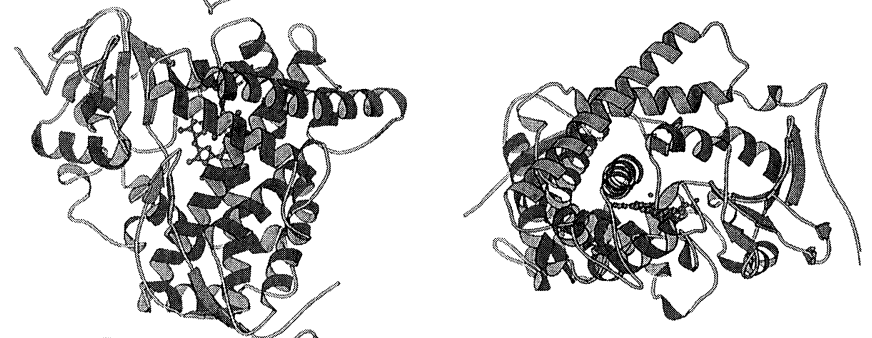

(c)

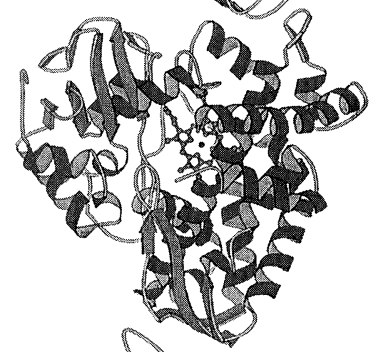

(d)

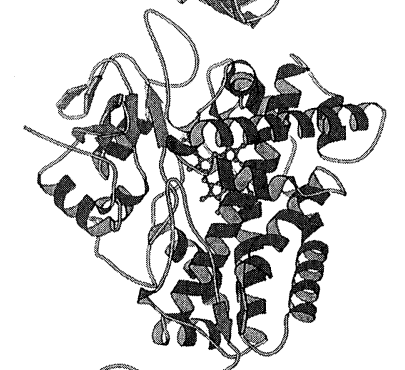

(e)
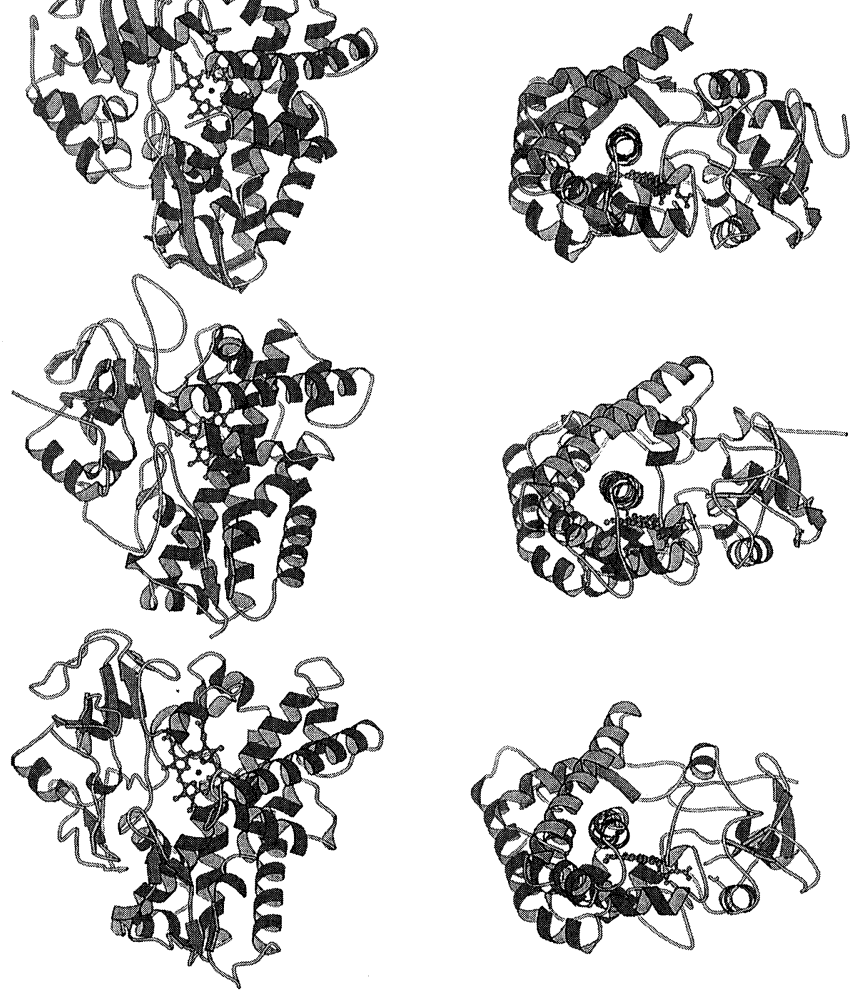

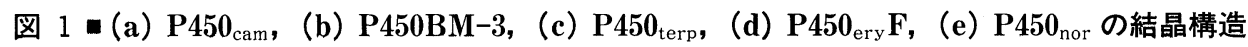

左図は分子を上から見た構造，右図は分子を横から（左図右上から）見た構造。へム， $\alpha$ ヘリックス， $\beta$ シート，ランダムコイル，Fおよ

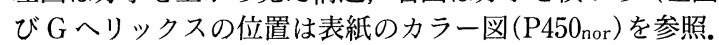

と呼ばれる領域と K ヘリックスの相互作用の様子など, 一次構造は数\%程度しか相同性を示さないにもかかわら ず，基本的な分子構造は非常によく似ている。このこと は, 個々の酵素の基質特異性, 反応の特異性は細部の構 造の違いで決まっていることを示している。

\section{2. 基質結合部位}

基質の結合 ${ }^{(6)}$ ・非結合型(7) の両方の構造が解析されて いるのは $\mathrm{P} 450_{\mathrm{cam}}$ のみである。この酵素の基質である樟 のう ( $d$-camphor) は，へムの第六配位座側（I ヘリッ クス側）に結合する，樟のうは 2 位のカルボニル基が酵 素の Tyr96 と水素結合し, 他の部位が周囲の蛋白質部 
分と踈水的および立体的な相互作用をしている．これら の相互作用が基質認識に重要であり,さらに酸素添加部 位である樟のうの 5-exo 位がへム鉄に向く配向を決定 している. 基質非結合型では樟のうの代わりに 6 つの水 分子よりなるクラスターが基質結合部位を占めている. そのうちの 1 つの水分子は第六配位子として鉄に配位し

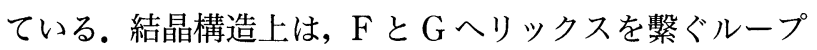
部分の温度因子が他の部位に比較して大きい（動きやす

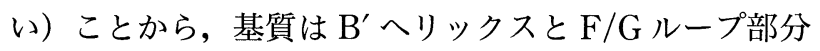
が摇らいでできる蹯水性の経路 (channel) を通って酵素 内部に入り込み，水分子クラスターを押し退けて結合部 位に結合すると推定されている。

P450BM-3 と P450terp は基質非結合型の構造のみ報 告されている，P450terp ではへムの第六配位座近傍に基 質結合部位と思われる蹯水性のポケットが存在する.F/ $\mathrm{G} ル ー フ ゚ は$ 結晶構造上では摇らいでしまって観測でき ず，この部位が基質の侵入経路と推定されている. P450BM-3 では， B'ヘリックスと F/G ループ部分を入 り口に蛋白質表面からへム鉄近傍まで続く空洞 (cavity) がみられる。この空洞は直径 $10 \AA$ ，長さ $20 \AA$ で，ちょ うど直鎖脂肪酸が入ることのできる広さであり，さらに この入り口付近には脂肪酸のカルボキシル基と相互作用 できるように塩基性アミノ酸 Arg47 が存在している。こ れにより，直鎖脂肪酸の $\omega$ 位 (酸素添加部位) が活性中 心近くに配向できるようになっている. $\mathrm{P} 450_{\text {ery }} \mathrm{F}$ と P450nor の基質結合については後述する.

以上のように，どの $\mathrm{P} 450$ でも $\mathrm{B}^{\prime}$ ヘリックス・F/Gル ープの部位が基質の結合に関与している。しかし，この 部位, 特に $\mathrm{B}^{\prime}$ ヘリックスの分子内での位置は, それぞれ の酵素で大きく異なっており，個々の酵素に特徵的な基 質認識と対応している。

\section{3. 還元酵素との相互作用}

P450 の一原子酸素添加反応には, 還元酵素より供給 される 2 電子が利用される. P450 と還元酵素の相互作 用を構造を基に見てみよう。

$\mathrm{P} 450$ は酸性蛋白質 $\left[\mathrm{P} 450_{\mathrm{cam}}(\mathrm{p} I=5.05), \mathrm{P} 450_{\text {terp }}\right.$ (5.02)，P450BM-3（5.62)]であるが，蛋白質表面の電 荷分布には偏りがある。へムの第六配位子側の蛋白質表 面には負電荷をもつアミノ酸側鎖が多く存在しているの に対し，逆に第五配位子側の蛋白質表面には正電荷をも つ塩基性アミノ酸残基（Arg，Lys）がかたまって存在す る部位がある。一方の $\mathrm{P} 450_{\mathrm{cam}}$ と $\mathrm{P} 450_{\mathrm{terp}}$ のそれぞれの 還元酵素も酸性蛋白質（pI=4.16，3.38）である。この ため還元酵素は P450 の第六配位子側の蛋白質表面とは
相互作用できず，第五配位子側の蛋白質表面でのみ静電 的な相互作用が可能である. 部位特異的変異法を用いた 解析で, P450 cam の第五配位子側蛋白質表面の Arg112 が還元酵素 putidaredoxin との相互作用に重要である ことが確かめられている(8).ちなみに, putidaredoxin の立体構造は NMR 法で解かれ, P450 cam との結合模擬 実験でもこのことは確かめられている。

\section{4. プロトンチャンネル}

P450cam, P450BM-3, P450terp の Iヘッリクスの真ん 中, 鉄の第六配位座のすぐ近くに Thr 残基が存在して いる.この Thr は大部分の P450に保存されており, “conserved Thr” と呼ばれている.このThrの水酸基 は，4つ手前の残基の主鎖のカルボニル基と水素結合を している.この特徴的な水素結合により，Iへリックス はこの部分で少し伸びた形になり，鉄に結合した酸素が 収まるポケットを形成している. conserved Thr は, さらにいくつかの水分子・アミノ酸側鎖と水素結合ネッ トワークを形成し，それを介して溶媒の水につながって いる.この水素結合ネットワークは, 詳細な結合パター ンは異なるものの, P450 cam, P450BM-3, P450terp い ずれにも存在し，一原子酸素添加反応に用いられるプ ロトンの供給経路と考えられている. 事実, P450 cam の Thr252Ala 変異体は, 酸素結合ポケットに新たな水分 子が入り込み, プロトン移動が制御できなくなった結果, 樟のうの水酸化活性を示さず, 酸素の還元生成物 (過酸化 水素)が生じることが確認されている (uncoupling reaction) ${ }^{(10,11)}$.

$\mathrm{P} 450_{\mathrm{ery}} \mathrm{F}$ は抗生物質エリスロマイシン (erythromycin A）の生合成の最初の段階（6-deoxyerythronolide B (6-DEB) の 6 位の立体特異的な水酸化) を触 媒する. P450ery F については 6-DEB との複合体の構造 が報告されている，6-DEB はへムの第六配位座近傍に ある広い基質結合部位に，6位が鉄の近くに配向するよ うに結合する.この近傍には多くの水分子が存在し, 水 素結合により基質と酵素を橋渡ししている.さらに, 疎 水性相互作用により基質の結合は安定化されている. $\mathrm{P} 450_{\text {ery }} \mathrm{F}$ の構造上の最大の特徵は, その I ヘリックスに conserved Thr が存在せず, 対応する位置が Ala にな っている点である. その代わり, 基質 6-DEB の 5 位の 水酸基が水分子 (鉄から $3.8 \AA$ ) と水素結合し, さらにい くつかの水分子と, Ala241, Gly242, Ser246, Glu360な どの側鎖・主鎖を通して水素結合ネットワークを作り, 溶媒とつながっている.このネットワークが P 450 ery $\mathrm{F}$ のプロトン供給系と考えられている. 実際, 6-DEBの 
5 位の水酸基をケト基に変えた分子 $(5,6-\mathrm{DOEB})$ は基質 とはならない(12).

\section{一酸化窒素還元酵素 $\mathbf{P} 450_{\text {nor }}$}

P450nor は, 基本的な構造は他の P450 に類似してい るが, 一原子酸素添加酵素ではなく, 一酸化窒素還元酵 素 $\left(2 \mathrm{NO}+\mathrm{NADH}+\mathrm{H}^{+} \longrightarrow \mathrm{N}_{2} \mathrm{O}+\mathrm{H}_{2} \mathrm{O}+\mathrm{NAD}^{+}\right.$を触 媒する）である. 反応で利用される 2 電子が還元酵素類 を介さず直接 NADH からへム部分に伝達される点も特 徵的である.これらの機能上の特徴を考慮しながら， $\mathrm{P} 450$ nor の構造を見てみる。

\section{1. 電子供与体 NADH の結合部位}

P450nor は活性中心のへム上部に異常に広い空洞部 （cavity）をもっており，他の P450 の基質結合に対応す るように, この部分が $\mathrm{NADH}$ の結合部位と想像されて いる. 一方で, 触媒反応の律速段階である NADH と $\mathrm{P} 450_{\text {nor }}\left(\mathrm{Fe}^{3+} \mathrm{NO}\right)$ との反応が, 重水効果を受けない実験 事実がある。これらのことより, NADH はへムのごく 近傍に結合することにより，へム鉄に結合した一酸化窒 素分子への水素陰イオン $\left(\mathrm{H}^{-}\right)$移動の形の直接 2 電子移 動を可能にしている.これにより生じる反応中間体 $\left(\mathrm{Fe}^{3+} \mathrm{NO}^{2-} 2 \mathrm{H}^{+}\right)$は, もう 1 分子の $\mathrm{NO}$ と反応し $\mathrm{N}_{2} \mathrm{O}$ と $\mathrm{H}_{2} \mathrm{O}$ が生じる(13).

\section{2. プロトンチャンネル}

P450nor には他の多くの P450 同様に I ヘリックス に conserved Thr (Thr243) が存在している.この Thr 243の水酸基は 2 つの水分子をはさんで Ala239 主 鎖のカルボニル基と水素結合をしている. $\mathrm{P} 450$ nor $の$ Thr243Asn 変異体は 60 ～ $80 \%$ 程度活性があるのに対 し, Thr243Val 変異体はほとんど活性がなく, Thr243 の水素結合が一酸化窒素還元反応に必須であることは確 かである. しかし，この水素結合はネットワークを作っ ておらず溶媒の水とはつながっていない。これらの結果 より, P450nor の Thr243 は, プロトン供給系としてょり も, $\mathrm{NADH}$ の結合あるいは電子 $\left(\mathrm{H}^{-}\right)$伝達に関与してい るのではないかと想像されている.

一方， $\mathrm{P} 450_{\text {nor }}$ の $\mathrm{Fe}^{2+} \mathrm{CO}$ 型の構造をみると，鉄に配 位した CO 分子の近傍（約 $3 \AA$ の距離）に水分子(Wat8) が存在し, そこから Wat8-Ser286- $\mathrm{H}_{2} \mathrm{O}-\mathrm{Asp} 393-$ 溶媒とつながる水素結合ネットワークを確認した。 Ser286Val 変異体では, 反応中間体の生成速度と一酸化 窒素還元活性共に大きく減少している. 以上のことよ
り，このSer286 を含む水素結合ネットワークが反応中 間体の生成の際に利用されるプロトン供給に関係してい ると結論した.いずれにせよ, NADH 結合型 P450nor と 各種変異体の構造解析が待たれる.

P450nor が一原子酸素添加反応を触媒しないのは, 第 一に第六配位子の近傍に水分子が存在し, 酸素化型 $\left(\mathrm{Fe}^{2+} \mathrm{O}_{2}\right)$ が非常に不安定であるため, 第二に電子供与体 $\mathrm{NADH}$ がへム鉄のごく近傍に結合するため， 1 電子ず つの逐次的な電子移動が不可能なためと考えられてい る.

$\mathrm{P} 450$ スーパーファミリーの中で大部分を占める真核 生物の膜結合型酵素の構造は未だ解かれていない.しか し，現在まで報告されている 5 種類の $\mathrm{P} 450$ の立体構造 から，P450の構造の基本的・普遍的特徴はほぼ理解でき るであろう。事実，これらを基にしたモデリングも盛ん に行なわれている（本稿では守備範囲を越えるため触れ なかった). 今後構造解明される P450では, 個々の P450 のもつ個性に注目するべきであろう。

\section{文献}

1) T.L. Poulos, B.C. Finzel, I.C. Gunsalus, G.C. Wagner \& J. Kraut: J. Biol. Chem., 260, 16122 (1985).

2) K.G. Ravichandran, S.S. Boddupalli, C.A. Haseman, J.A. Peterson \& J. Deisenhofer: Science, 261, 731 (1993).

3) C.A. Haseman, K.G. Ravichandran, J.A. Peterson \& J. Deisenhofer: J. Mol. Biol., 236, 1169 (1994).

4) J.R. Cupp-Vickery \& T.L. Poulos : Nature Str. Biol., 2, 144 (1995).

5) S.-Y. Park, H. Shimizu, S. Adachi, A. Nakagawa, I. Tanaka, K. Nakahara, H. Shoun, E. Obayashi, H. Nakamura, T. Iizuka \& Y. Shiro : Nature Str. Biol., 4, 827 (1997).

6) T.L. Poulos, B.C. Finzel \& A.J. Howard : J. Mol. Biol., 195, 687 (1987).

7) T.L. Poulos, B.C. Finzel \& A.J. Howard : Biochemistry, 25, 5314 (1986).

8) M. Unno, H. Shimada, Y. Toba, R. Makino \& Y. Ishimura : J. Biol. Chem., 271, 17869 (1996).

9) T.C. Pochapsky, G. Ratnaswamy \& A. Patera : Biochem istry, 33, 6433 (1994).

10) M. Imai, H. Shimada, Y. Watanabe, Y. MatsushimaHibiya, R. Makino, H. Koga, T. Horinouchi \& Y. Ishimura: Proc. Natl. Acad. Sci. USA, 86, 7823 (1989).

11) R. Raag, S.A. Martinis, S.G. Sligar \& T.L. Poulos : Biochemistry, 30, 11420 (1991).

12) J.R. Cupp-Vickery, O. Han, C.R. Hutchinson \& T.L. Poulos: Nature Str. Biol., 3, 632 (1996).

13) Y. Shiro, M. Fujii, T. Iizuka, S. Adachi, K. Tsukamoto, K. Nakahara \& H. Shoun: J. Biol. Chem., 270, 1617 (1995). 